\title{
Evaluation of Some Mycorrhizae Strains on Improving Nutrients Absorption in Maize Plant Grown in (Sirte-Libya) Saline Soil
}

\author{
Salma O. Jadallah ${ }^{1}$, Ahlam H. ALsaadi ${ }^{2} \&$ Ahmed A. Rahim majeed ${ }^{3}$ \\ ${ }^{I}$ Department of Botany, Faculty of Science, ${ }^{2}$ Department of Soil and Water, Faculty of Agriculture, ${ }^{3}$ Department of Soil Science, \\ Faculty of Agriculture, ${ }^{1-3}$ Omar El-Mokhtar University, Al-Baida, Libya.
}

DOI: http://doi.org/10.46382/MJBAS.2021.5304

Copyright: @2021 Salma O. Jadallah et al. This is an open access article distributed under the terms of the Creative Commons Attribution License, which permits unrestricted use, distribution, and reproduction in any medium, provided the original author and source are credited.

In an experiment, maize plants were inoculated with seven strains of mycorrhizae fungi previously isolated from AL-Jabal AL-Akhdar forests AMF strains: (Rhizophagus intraradices, Claroideoglomus etunicatum, Gigspora sp., Entrophos Porainfeqeas, Scutellospora sp., Archaeospora trappei, funneliformis mosseae) maize seeds planted in sandy soil in pots and either inoculated or not with a single inocula strain of the examined AFM strains. Phosphorus was applied as mono-calcium phosphate at the recommended rates of application three levels of phosphate fertilization: (with out of phosphate fertilizer: F0), (addition of super phosphate at aerate of $50 \mathrm{~kg} / \mathrm{ha}$ : F1), (add of super phosphate at aerate of $100 \mathrm{~kg} / \mathrm{ha}: \mathrm{F} 2$ ). After harvesting the maize plant, the content of the leaves was estimated from the following nutrients: (N, P K, Fe, Zn), the results showed that most of them gave a significant increase in the plant content of these nutrients. Effect of phosphate fertilization with inoculation mycorrhizal strains deficiency in the concentration of some nutrient with in plant compared to treatment inoculated without adding phosphate fertilizer.

Keywords: Arbuscular mycorrhizal, Evaluation, Maize, Saline soil, Nutrient uptake.

\section{Introduction}

The majority of terrestrial vascular plants are capable of forming mutualistic associations with obligate biotrophic arbuscular mycorrhizal (AM) fungi from the phylum Glomeromycota ${ }^{(1)}$. This symbiosis gives benefits to the plant's growth and development through the facilitation of Phosphorus and some other mineral nutrients from the soil by the arbuscular mycorrhizal ${ }^{(2)}$. The main advantage of mycorrhiza is its better soil beneficiary and increasing uptake of $\mathrm{N}, \mathrm{P}, \mathrm{K}, \mathrm{Zn}, \mathrm{Cu}, \mathrm{S}, \mathrm{Fe}, \mathrm{Ca}, \mathrm{Mg}$ and $\mathrm{Mn}$ supply to the plant roots ${ }^{(3)}$. Arbuscular mycorrhizal fungi have been shown to improve crop productivity due to their contribution to plant nutrition and soil structure. The function of AMF is attributed to increased plant $\mathrm{P}$ uptake as a consequence of their high affinity $\mathrm{P}$ uptake mechanism ${ }^{(4)}$. Mycorrhizal biodiversity can effectively contribute to nutrient and water efficiency ${ }^{(5)}$.

Previous studies have indicated that AMF can confer salt tolerance to host plants by stimulating enzyme activity protection systems, increasing photosynthesis capacity and enhancing nutrients uptake ${ }^{(6)}$. AMF have the high efficiency to more the uptake of mineral nutrients in many plant species, especially of phosphate ${ }^{(7)}$. In study aimed to evaluate the interactions between arbuscular mycorrhizal fungi (Glomus mosseae), tea residue, macroalgae biomass and its subsequent effects on carbon mineralisation, actinomycetes counts, nutrients content, chlorophyll content, and corn growth (Zea mays L.).

Results showed that only treatment tea residue had the highest of carbon mineralization, while it was lower in the (Glomus mosseae $)+$ tea residue treatments. Addition the large values of actinomycetes, chlorophyll, phosphorous content and roots weight in Glomus mosseae) + tea residue treatments, as compared to the without treatment. Can be beneficial to ecosystems through facilitating carbon conservation and microbial diversity in arid saline soils ${ }^{(8)}$. Improvement in fresh and dry weights, and nitrogen concentration of shoot and root due to mycorrhizal inoculation 
under saline conditions. Plants possessing AMF show enhanced many important nutrients ${ }^{(9)}$. Because of the public concerns about the side effects of chemical fertilizer, major attention has been given to research areas concerning arbuscular mycorrhiza as biofertilizer. Despite the importance of arbuscular mycorrhiza in agriculture and forestry.

\section{Materials and Methods}

(1) Study Site: A Libyan city located in the north on overlooking the Mediterranean Sea. (2) The pot experiment was conducted during the period extended from 1 March to 30 May 2020 at the greenhouse of the Institute of Bioscience (IBS), Omar Al-Mukhtar University, Al-Bayda, Libya to know the effect of inoculation with seven AMF strains: Rhizophagus intraradices (MF599223), Claroideoglomus etunicatum (MF599211), Gigspora sp (MF599222), Entrophos Porainfeqeas (MF 599211), Scutellospora sp., (MF599226), Archaeospora trappei (MF599213), funneliformis mosseae (mf599221), previously isolated from the (AL-Jabal AL-Akhdar forestsLibya) ${ }^{(10) .}$ (3) Application of endomycorrhizae: A commercially and A cultivar of Zea mays L., that belongs to the Graminae family. Three maize seeds were surface-sterilized, planted in a $10 \mathrm{~kg}$ pot $(40 \mathrm{x} 40 \mathrm{~cm})$ and inoculated with single-strain AFM inocula: addition fungal species of mycorrhizae identified as seedbed, as biofertilizer consisting of fungus spores, infected roots and soil resulting from propagation, treatment Mycorrhizae: M0: Control, Rhizophagus intraradices (MF599223), Claroideoglomus etunicatum (MF599211), Gigspora sp (MF599222), Entrophos Porainfeqeas (MF 599211), Scutellospora sp., (MF599226), Archaeospora trappei (MF599213), funneliformis mosseae (MF599221). (4) Addition of three phosphate fertilization levels: with out of phosphate fertilizer, addition of super phosphate ( $\mathrm{F} 0=$ without adding phosphorus), ( $\mathrm{F} 1=$ Add super phosphate Triplex at $50 \mathrm{~g} / \mathrm{h}),(\mathrm{F} 2=$ add of super phosphate at aerate of $100 \mathrm{~kg} / \mathrm{ha})$.

\section{Nutrient analysis}

To determine the mineral contents, oven-dried shoots were powdered, and the powder was digested with $98 \%$ $\mathrm{H}_{2} \mathrm{SO}_{4}$ and $30 \% \mathrm{H}_{2} \mathrm{O}_{2}$. The phosphorus (P) content was estimated using the Olsen method ${ }^{(11)}$. The content potassium was determined in tissue plant, by (Flame Photometry: JENWAY, PFP7) ${ }^{(12)}$. Soil Analysis: The physical and chemical properties of the Soil: texture, $\mathrm{pH}, \mathrm{EC}$, available nitrogen and available phosphorus ${ }^{(13)}$.

Table 1. Physical and chemical characteristics of soil in the study location

\begin{tabular}{|l|l|}
\hline Physical properties & Value \\
\hline Bulk density $\mathrm{g} / \mathrm{cm}^{3}$ & $\mathbf{1 . 6 4}$ \\
\hline Field capacity \% & $\mathbf{1 8 . 5 1 8 1}$ \\
\hline Soil texture & sandy \\
\hline Clay \% & $\mathbf{8}$ \\
\hline Silt \% & $\mathbf{1 5}$ \\
\hline Sand \% & $\mathbf{7 7}$ \\
\hline Moisture content \% & $\mathbf{1 . 4 6}$ \\
\hline Chemical Properties & Value \\
\hline PH & $\mathbf{8 . 4}$ \\
\hline Electrical connection $\mathbf{d S ~} \mathbf{~}^{-1}$ & $\mathbf{6 . 5 8}$ \\
\hline
\end{tabular}




\begin{tabular}{|l|l|l|}
\hline \multirow{4}{*}{$\begin{array}{c}\text { Dissolved } \\
\text { ions }\end{array}$} & $\mathrm{Ca}^{+}$ & $\mathbf{2 0}$ \\
\cline { 2 - 3 } & $\mathrm{Mg}^{+2}$ & 25 \\
\cline { 2 - 3 } & $\mathrm{K}^{+}$ & 10 \\
\cline { 2 - 3 } & $\mathrm{Cl}^{-}$ & 4.75 \\
\cline { 2 - 3 } & $\mathrm{Co}_{3}{ }^{-2}$ & 0 \\
\hline Cation Exchange Capacity & 21.4 \\
\hline Calcium Carbonate \% & 3.75 \\
\hline Available Phosphorous Mg/L & 3.14 \\
\hline Organic Matter \% & 1.58 \\
\hline \multicolumn{2}{|c|}{ Total Nitrogen $\mathrm{Mg} / \mathrm{L}$} & 34.2 \\
\hline
\end{tabular}

\section{Statistical analysis}

Data were statistically analyzed for ANOVA was calculated at P $<0.001$ using SPSS 19.0 statistical program (SPSS Inc., Chicago, IL, USA). Two independent statistical analyses, the first to analyze data from the different AMF treatments within saline soil and with the three phosphate fertilization levels, analyze data from each fungal species at phosphate fertilization levels.

\section{Result}

In Table No.2, the results showed that the inoculation with mycorrhizal fungi helped effect a significant increase in the phosphorous content of the leaves, where the highest phosphorous content was when inoculating with the fungus (Scutellospora sp.) and its value was $38.43 \mathrm{mg} / \mathrm{dry}$ weight of the leaves compared to the control. As for adding phosphate fertilizer as super phosphate fertilizer, it led to an increase in phosphorus content of leaves, but the increase was not significant. And there are some strains of mycorrhizal (Clarhoideoglomus etunicatum), (Scutellospora sp.,), (funneliformis mosseae), (Entrophos Porainfeqeas) when they interaction with the two levels of phosphate fertilization (50 and $100 \mathrm{~kg}$ phosphorus/ha) led to a decrease in the phosphorous content of the plant.

Table 2. Effect of inoculation with strains of mycorrhizal fungi on concentration of Phosphorus $\mathrm{mg} / 100 \mathrm{~g}$ dry weight leaves

\begin{tabular}{|c|c|c|c|c|}
\hline \multirow{2}{*}{ Mycorrhizae } & \multicolumn{3}{|c|}{ Fertilizer $P$ as super phosphate } & \multirow{2}{*}{$\begin{array}{l}\text { Mycorrhizae } \\
\text { average }\end{array}$} \\
\hline & $0 \mathrm{~kg}$ p/ha & $50 \mathrm{~kg}$ p/ha & $100 \mathrm{~kg} \mathrm{p} / \mathrm{ha}$ & \\
\hline No inocula mycorrhizal & $25.93 \pm 0.38$ & $28.00 \pm 2.43$ & $29.57 \pm 2.80$ & $27.83 \pm 2.44$ \\
\hline Rhizophagus intraradices & $28.03 \pm 2.45$ & $40.77 \pm 0.59$ & $29.67 \pm 4.19$ & $32.82 \pm 6.48$ \\
\hline Clarhoideoglomus etunicatum & $33.47 \pm 6.81$ & $27.43 \pm 1.70$ & $29.23 \pm 3.75$ & $30.04 \pm 4.80$ \\
\hline Gigspora sp. & $29.00 \pm 3.30$ & $33.10 \pm 6.53$ & $24.80 \pm 1.30$ & $28.97 \pm 5.17$ \\
\hline Entrophos Porainfeqeas & $36.20 \pm 1.87$ & $30.47 \pm 0.25$ & $40.90 \pm 0.44$ & $35.86 \pm 4.63$ \\
\hline Scutellospora sp. & $38.43 \pm 1.16$ & $29.20 \pm 0.36$ & $30.43 \pm 0.31$ & $32.69 \pm 4.39$ \\
\hline Archaeospora trappei & $22.17 \pm 0.99$ & $34.17 \pm 0.84$ & $36.13 \pm 5.14$ & $30.82 \pm 7.06$ \\
\hline funneliformis mosseae & $29.17 \pm 1.01$ & $28.20 \pm 2.43$ & $23.97 \pm 1.50$ & $27.11 \pm 2.83$ \\
\hline
\end{tabular}




\begin{tabular}{|c|c|c|c|}
\hline Fertilizer $P$ average & $30.30 \pm 5.72$ & $31.42 \pm 4.85$ & $30.59 \pm 5.88$ \\
\hline F-value & $\begin{array}{l}\text { For fertilize } \\
\text { For Mycorı } \\
\text { For } \mathbf{F}+\mathbf{M} \rightarrow\end{array}$ & $\begin{array}{l}\mathbf{P} \rightarrow 0.97 \\
. \mathbf{z a e} \rightarrow 9.24 * \\
96^{* * *}\end{array}$ & \\
\hline
\end{tabular}

*** Significant variation at $\mathrm{P}<0.001$

In Table No.3, the results showed that the inoculation with mycorrhizal fungi led to a significant increase in the nitrogen content of the leaves, where the highest nitrogen content was when inoculating with the fungus funneliformis mosseae and Gigspora sp., the increase values for the two types was $15 \mathrm{mg} / \mathrm{dry}$ weight of the leaves compared to the control, this may be due to what was found in a previous study, The hyphae of AMF have the tendency to extract nitrogen and transport it from the soil to plants. They contain enzymes that breakdown organic nitrogen and contain nitrogen reductase which alters the forms of nitrogen in the soil. AM improves growth, nodulation and nitrogen fixation in legume - Rhizobium symbiosis ${ }^{(14)}$. The transport of ammonium to the plant is better when there is presence of mycorrhizea ${ }^{(15) .}$

Table 3. Inoculation with strains of mycorrhizal fungi on concentration of Nitrogen $\mathrm{mg} / 100 \mathrm{~g}$ dry weight leaves

\begin{tabular}{|c|c|c|c|c|}
\hline \multirow{2}{*}{ Mycorrhizae } & \multicolumn{3}{|c|}{ Fertilizer $P$ as super phosphate } & \multirow{2}{*}{$\begin{array}{l}\text { Mycorrhizae } \\
\text { average }\end{array}$} \\
\hline & $0 \mathrm{~kg} \mathrm{p} / \mathrm{ha}$ & $50 \mathrm{~kg}$ p/ha & $100 \mathrm{~kg} \mathrm{p} / \mathrm{ha}$ & \\
\hline No inocula mycorrhizal & $12.57 \pm 0.50$ & $14.27 \pm 1.36$ & $12.93 \pm 0.12$ & $13.26 \pm 1.06$ \\
\hline Rhizophagus intraradices & $14.90 \pm 0.70$ & $13.83 \pm 0.35$ & $13.93 \pm 1.02$ & $14.22 \pm 0.82$ \\
\hline Clarhoideoglomus etunicatum & $14.73 \pm 0.68$ & $13.57 \pm 0.40$ & $14.23 \pm 0.95$ & $14.18 \pm 0.80$ \\
\hline Gigspora sp. & $15.17 \pm 0.06$ & $12.83 \pm 0.32$ & $15.10 \pm 0.60$ & $14.37 \pm 1.20$ \\
\hline Entrophos Porainfeqeas & $14.70 \pm 1.00$ & $13.93 \pm 0.23$ & $13.63 \pm 0.12$ & $14.09 \pm 0.70$ \\
\hline Scutellospora sp. & $14.77 \pm 0.74$ & $13.87 \pm 0.61$ & $13.77 \pm 0.64$ & $14.13 \pm 0.75$ \\
\hline Archaeospora trappei & $14.60 \pm 0.56$ & $14.37 \pm 1.17$ & $14.93 \pm 0.96$ & $14.63 \pm 0.84$ \\
\hline funneliformis mosseae & $15.20 \pm 0.61$ & $14.70 \pm 0.72$ & $14.63 \pm 0.50$ & $14.84 \pm 0.60$ \\
\hline Fertilizer $P$ average & $14.58 \pm 0.97$ & $13.92 \pm 0.83$ & $14.15 \pm 0.91$ & \\
\hline F-value & \multicolumn{4}{|c|}{$\begin{array}{l}\text { For fertilizer } \mathbf{P} \rightarrow \mathbf{5 . 4 0 5}^{* *} \\
\text { For Mycorrhizae } \rightarrow 3.978^{* *} \\
\text { For } \mathbf{F}+\mathbf{M} \rightarrow 2.715^{* *}\end{array}$} \\
\hline
\end{tabular}

*** Significant variation at $\mathrm{P}<0.001$

In Table No.4, the results showed the effect of inoculation with different strains on the concentration of potassium in the leaves of corn plant where the inoculation of all tested species had significant effect on the potassium concentration and inoculation with each strains (Clarhoideoglomus etunicatum, Entrophos Porainfeqeas, Archaeospora trappei) the highest concentration of potassium was the value $30 \mathrm{mg} / \mathrm{dry}$ weight leaves. It was 
observed from the results that the potassium concentration in the leaves of plant decreased when inoculating with most of the strains with addition of the two levels of phosphate fertilization compared to the inoculated treatments without the addition of phosphate fertilizer.

Table 4. Inoculation with strains of mycorrhizal fungi on concentration Potassium $\mathrm{mg} / 100 \mathrm{~g}$ dry weight leaves

\begin{tabular}{|c|c|c|c|c|}
\hline \multirow{2}{*}{ Mycorrhizae } & \multicolumn{3}{|c|}{ Fertilizer $P$ as super phosphate } & \multirow{2}{*}{$\begin{array}{l}\text { Mycorrhizae } \\
\text { average }\end{array}$} \\
\hline & $0 \mathrm{~kg} \mathrm{p} / \mathrm{ha}$ & $50 \mathrm{~kg}$ p/ha & $100 \mathrm{~kg} \mathrm{p} / \mathrm{ha}$ & \\
\hline No inocula mycorrhizal & $23.13 \pm 1.27$ & $29.50 \pm 1.66$ & $22.23 \pm 0.67$ & $24.96 \pm 3.60$ \\
\hline Rhizophagus intraradices & $28.77 \pm 4.37$ & $22.87 \pm 1.58$ & $22.17 \pm 1.15$ & $24.60 \pm 3.95$ \\
\hline Clarhoideoglomus etunicatum & $28.57 \pm 1.85$ & $30.60 \pm 3.10$ & $30.91 \pm 2.80$ & $30.02 \pm 2.54$ \\
\hline Gigspora sp & $27.63 \pm 3.05$ & $27.90 \pm 5.12$ & $26.17 \pm 1.50$ & $27.23 \pm 3.18$ \\
\hline Entrophos Porainfeqeas & $36.43 \pm 2.70$ & $24.82 \pm 4.67$ & $31.23 \pm 2.35$ & $30.83 \pm 5.84$ \\
\hline Scutellospora sp., & $38.87 \pm 1.54$ & $28.30 \pm 2.14$ & $18.93 \pm 2.03$ & $28.70 \pm 8.80$ \\
\hline Archaeospora trappei & $29.00 \pm 1.28$ & $33.73 \pm 2.50$ & $28.63 \pm 1.79$ & $30.46 \pm 2.97$ \\
\hline funneliformis mosseae & $34.83 \pm 1.74$ & $23.03 \pm 2.74$ & $30.73 \pm 3.15$ & $29.53 \pm 5.66$ \\
\hline Fertilizer $P$ average & $30.91 \pm 5.43$ & $27.59 \pm 4.51$ & $26.38 \pm 4.87$ & \\
\hline F-value & \multicolumn{4}{|c|}{$\begin{array}{l}\text { For fertilizer } \mathbf{P} \rightarrow 19.33^{* * * *} \\
\text { For Mycorrhizae } \rightarrow 7.861^{* * *} \\
\text { For } \mathbf{F}+\mathbf{M} \rightarrow 10.35^{* * *}\end{array}$} \\
\hline
\end{tabular}

*** Significant variation at $\mathrm{P}<0.001$

In Table No.5, the results showed the effect of inoculation with different strains on the concentration of iron and zinc in the leaves of corn plant where the inoculation of all tested species had significant, effect on the iron concentration, inoculation with inoculation with strains (Archaeospora trappei), (funneliformis mosseae), (Gigspora sp) and (Clarhoideoglomus etunicatum) the highest concentration of iron were recorded, respectively $(0.24,0.24,0.23$ and 0.22$) \mathrm{mg} /$ dry weight leaves.

Table 5. Inoculation with diverse strains of mycorrhizal fungi on concentration of iron $\mathrm{mg} / 100 \mathrm{~g}$ dry weight leaves

\begin{tabular}{|l|l|l|l|l|}
\hline \multirow{2}{*}{ Mycorrhizae } & \multicolumn{2}{|l|}{ Fertilizer P as super phosphate } & \multirow{2}{*}{$\begin{array}{l}\text { Mycorrhizae } \\
\text { average }\end{array}$} \\
\cline { 2 - 5 } & $\mathbf{0} \mathbf{~ k g}$ p/ha & $\mathbf{5 0} \mathbf{~ k g}$ p/ha & $\mathbf{1 0 0} \mathbf{~ k g}$ p/ha & \\
\hline No inocula mycorrhizal & $0.15 \pm 0.01$ & $0.14 \pm 0.02$ & $0.15 \pm 0.01$ & $\mathbf{0 . 1 5} \pm \mathbf{0 . 0 1}$ \\
\hline Rhizophagus intraradices & $0.16 \pm 0.01$ & $0.19 \pm 0.03$ & $0.21 \pm 0.03$ & $\mathbf{0 . 1 9} \pm \mathbf{0 . 0 3}$ \\
\hline Clarhoideoglomus etunicatum & $0.20 \pm 0.01$ & $0.24 \pm 0.01$ & $0.24 \pm 0.00$ & $\mathbf{0 . 2 2} \pm \mathbf{0 . 0 2}$ \\
\hline Gigspora sp & $0.29 \pm 0.01$ & $0.19 \pm 0.02$ & $0.22 \pm 0.01$ & $\mathbf{0 . 2 3} \pm \mathbf{0 . 0 4}$ \\
\hline Entrophos Porainfeqeas & $0.20 \pm 0.00$ & $0.21 \pm 0.04$ & $0.15 \pm 0.01$ & $\mathbf{0 . 1 9} \pm \mathbf{0 . 0 3}$ \\
\hline
\end{tabular}




\begin{tabular}{|l|l|l|l|l|}
\hline Scutellospora sp., & $0.22 \pm 0.05$ & $0.21 \pm 0.03$ & $0.21 \pm 0.01$ & $\mathbf{0 . 2 1} \pm \mathbf{0 . 0 3}$ \\
\hline Archaeospora trappei & $0.24 \pm 0.03$ & $0.24 \pm 0.04$ & $0.24 \pm 0.05$ & $\mathbf{0 . 2 4} \pm \mathbf{0 . 0 3}$ \\
\hline funneliformis mosseae & $0.23 \pm 0.01$ & $0.25 \pm 0.01$ & $0.24 \pm 0.00$ & $\mathbf{0 . 2 4} \pm \mathbf{0 . 0 1}$ \\
\hline Fertilizer P average & $\mathbf{0 . 2 1} \pm \mathbf{0 . 0 5}$ & $\mathbf{0 . 2 1} \pm \mathbf{0 . 0 4}$ & $\mathbf{0 . 2 1} \pm \mathbf{0 . 0 4}$ & $\mathbf{0 . 2 1} \pm \mathbf{0 . 0 4}$ \\
\hline F-value & $\begin{array}{l}\text { For fertilizer } \mathbf{P} \rightarrow 0.02 \\
\text { For } \mathbf{M y c o r r h i z a e} \rightarrow 17.14 * * * \\
\text { For } \mathbf{F}+\mathbf{M} \rightarrow 3.564 * * *\end{array}$ \\
\hline
\end{tabular}

*** Significant variation at $\mathrm{P}<0.001$

Table No.6 shows the effect of inoculation with the studied strain of mycorrhizea on the zinc concentration content of plant, inoculation with inoculation with strains (Rhizophagus intraradices), (Archaeospora trappei), (Scutellospora sp.), (Clarhoideoglomus etunicatum) and (Entrophos Porainfeqeas) the highest concentration of zinc were recorded, respectively $(0.60,0.44,0.40,0.39$ and 0.32$) \mathrm{mg} /$ dry weight leaves.

Table 6. Inoculation with strains of mycorrhizal fungi on concentration of Zinc mg/100g dry weight leaves

\begin{tabular}{|c|c|c|c|c|}
\hline \multirow{2}{*}{ Mycorrhizae } & \multicolumn{3}{|c|}{ Fertilizer $P$ as super phosphate } & \multirow{2}{*}{$\begin{array}{l}\text { Mycorrhizae } \\
\text { average }\end{array}$} \\
\hline & 0 kg p/ha & $50 \mathrm{~kg}$ p/ha & $100 \mathrm{~kg}$ p/ha & \\
\hline No inocula mycorrhizal & $0.020 \pm 0.001$ & $0.024 \pm 0.002$ & $0.024 \pm 0.003$ & $0.023 \pm 0.003$ \\
\hline Rhizophagus intraradices & $0.125 \pm 0.169$ & $0.028 \pm 0.006$ & $0.027 \pm 0.006$ & $0.060 \pm 0.098$ \\
\hline Clarhoideoglomus etunicatum & $0.017 \pm 0.015$ & $0.044 \pm 0.021$ & $0.056 \pm 0.001$ & $0.039 \pm 0.022$ \\
\hline Gigspora sp., & $0.045 \pm 0.005$ & $0.019 \pm 0.001$ & $0.025 \pm 0.005$ & $0.030 \pm 0.012$ \\
\hline Entrophos Porainfeqeas & $0.035 \pm 0.004$ & $0.022 \pm 0.001$ & $0.040 \pm 0.005$ & $0.032 \pm 0.009$ \\
\hline Scutellospora sp., & $0.045 \pm 0.011$ & $0.029 \pm 0.002$ & $0.046 \pm 0.003$ & $0.040 \pm 0.010$ \\
\hline Archaeospora trappei & $0.051 \pm 0.003$ & $0.030 \pm 0.027$ & $0.052 \pm 0.001$ & $0.044 \pm 0.017$ \\
\hline funneliformis mosseae & $0.043 \pm 0.002$ & $0.022 \pm 0.001$ & $0.027 \pm 0.006$ & $0.031 \pm 0.010$ \\
\hline Fertilizer $P$ average & $0.048 \pm 0.060$ & $0.027 \pm 0.013$ & $0.037 \pm 0.013$ & \\
\hline F-value & \multicolumn{4}{|c|}{$\begin{array}{l}\text { For fertilizer } \mathbf{P} \rightarrow 2.004 \\
\text { For Mycorrhizae } \rightarrow 0.938 \\
\text { For } \mathbf{F}+\mathbf{M} \rightarrow 1.152\end{array}$} \\
\hline
\end{tabular}

*** Significant variation at $\mathrm{P}<0.001$

\section{Discussions}

With greater consensus and the need to promote sustainable agriculture, the mycorrhiza plays an important in reducing the harmful effects of fertilizers and pesticides and improving plant growth and tolerance to salinity. AMF protects plants against abiotic stresses using various processes such, uptake and accumulation of mineral nutrients and changes in the rhizosphere ecosystem ${ }^{(16)}$. The efficiency o of AM fungi to extract nutrients in the root 
area is amazing and they release nutrients inside the plant with many paths of plant transporters activating symbiotic relation.

On the one hand, our results confirm that a broad range of crop plants can benefit from the inoculation with AMF, and that there is high potential for additional growth. On the other hand, our results suggest that specific arbuscular mycorrhizal taxa-host plant combinations enhance the growth of a crop growth parameters are shown to be increasing effectively and significantly in inoculated plants than controls. In all the experiments, the non-inoculated controls established the symbiosis; however inoculation resulted in higher plant yield and better plant nutrition ${ }^{(17)}$. Also, found that mycorrhizal inoculation of maize plants significantly increased leaf and shoot fresh and dry weight, root biomass and leaf area index ${ }^{(18)}$. Most of the tested strains were effective in facilitating the absorption of nutrient that were estimated in plant tissue but it was also noticed that there was a decrease in the concentration of some of them, such as phosphorous, when fertilization with the inoculation of some strains. Selection and optimization of mycorrhizal fungi according to the soil conditions is prerequisite for plant growth and sustainable agriculture. We need extensive studies to reveal, are the role of AMF in reducing the effects of combined stresses.

\section{Declarations}

\section{Source of Funding}

This research did not receive any grant from funding agencies in the public, commercial, or not-for-profit sectors.

\section{Competing Interests Statement}

The authors declare no competing financial, professional and personal interests.

\section{Ethical Approval}

Ethical approval for this research was given based on institutional guidelines.

\section{Consent for publication}

Authors declare that they consented for the publication of this research work.

\section{References}

1. Xie X., Lin H., Peng X., Xu C., Sun Z., Jiang K., Huang A., Wu X., Tang N., Salvioli A., Bonfante P., and Zhao B., (2016), Arbuscular Mycorrhizal Symbiosis Requires a Phosphate Transceptor in the Gigaspora margarita Fungal Symbiont., Molecular Plant 9, pp.1583-1608.

2. Ashok A.; Nisha K.; Anju T.; Alpa Y., and Gupta K., (2011), Role of arbuscular mycorrhizal fungi (AMF) in global sustainable development, Journal of Applied and Natural Science 3(2), pp.340-351.

3. Abdul Mallik, M., (2000), Association of arbuscular mycorrhizae with some varieties of Tobacco (Nicotiana tobacum L.) and its effect on their growth, nutrition and certain soil borne diseases, Ph.D. Thesis, Bharathidasan University, Tiruchirapalli, India, pp.104. 
4. Smith, S. E. \& Smith, F. A., (2012), Fresh perspectives on the roles of arbuscular mycorrhizal fungi in plant nutrition and growth, Mycologia 104, pp.1-13.

5. Brussaard L., DE Ruiter P.C., Brown G.G., (2007), Soil biodiversity for agricultural sustainability, Agr. Ecosyst. Environ., 121, pp.233-244.

6. Chen, S., Zhao, H., Chen, Y., Wang, Z., (2017), Combined Inoculation with multiple arbuscular mycorrhizal fungi improves growth, nutrient uptake and photosynthesis in cucumber seedlings, Front. Microbiol., 8, pp.25-16.

7. Nell, M., Wawrosch, C., Steinkellner, S., Vierheilig, H., Kopp, B., and Lössl, A., (2010), Root colonization by symbiotic arbuscular mycorrhizal fungi increases sesquiterpenic acid concentrations in Valeriana officinalis $L$. Planta Med., 76, pp.393-398.

8. Turrini, A., Bedini, A., Loor, M. B., Santini, G., Sbrana, C., Giovannetti, M., et al., (2018), Local diversity of native arbuscular mycorrhizal symbionts differentially affects growth and nutrition of three crop plant species, Biol. Fertil. Soils 54, pp.203-217.

9. Salwan A., Abbas A., Mohammed S., Amal R, and Duraid K.A. Al-Taey, (2021), Effects of Arbuscular Mycorrhiza and Organic Wastes on Soil Carbon Mineralisation, Actinomycete sand Nutrient Content in Maize Plants (Zea Mays L.)., Malaysian Journal of Soil Science,Vol.25, pp.107-124.

10. Salma O.; Manal M.; S. Elkobeisy and M. A. Ali, (2007), Phenotypic and phylogenetic diversity of mycorrhizae isolated from Al-Jabal Al-Akhdar, Libya, Bioscience Research 14(4), pp.915-923.

11. Olsen, S.R., Dean, L.A., (1965), Phosphorus Chemical and microbiological properties, methods of soil analysis, Part 2, pp.1035-1048.

12. Wolf, B., (1982), Communications in Soil Science and Plant Analysis: A comprehensive system of leaf analyses and its use for diagnosing crop nutrient status, Commun. Soil Sci. Plant Anal., 13, pp.1035-1059.

13. M.L Jackson, (1973), Soil chemical analysis, Prentice Hall, New Delhi.

14. Johnson, N.C., Tilman, D. and Wedin, D., (1992), Plant and soil control on mycorrhizal fungal communities, Ecology, 73, pp.2034-2042.

15. Guether, M., Balestrini, R., Hannah, M., He, J., Udvardi, M.K. and Bonfante, P., (2009), Genome-wide reprogramming of regulatory networks, transport, cell wall and membrane biogenesis during arbuscular mycorrhizal symbiosis in Lotus japonicas, New Phytologist., 182(1), pp.200-212.

16. Hashem, A., Alqarawi, A. A., Radhakrishnan, R., Al-Arjani, A. F., Aldehaish, H. A., Egamberdieva, D., et al., (2018), Arbuscular mycorrhizal fungi regulate the oxidative system, hormones and ionic equilibrium to trigger salt stress tolerance in Cucumis sativus L., Saudi J. Biol. Sci., 25(6), pp.1102-1114.

17. Ortas I., Varma A., (2007), Field trials of bio inoculants, In: Modern tools and techniques (Oelmüller R., Varma A., Eds.), Springer-Verlag 11, pp.397-409. 